\title{
Microstructures and properties of low-alloy fire resistant steel
}

\author{
BIMAL KUMAR PANIGRAHI \\ R\&D Centre for Iron and Steel, Steel Authority of India Limited, Ranchi 834 002, India
}

MS received 10 June 2004; revised 2 November 2005

\begin{abstract}
Microstructures and properties of weldable quality low-alloy fire resistant structural steels (YS: 287-415 MPa) and TMT rebar (YS: 624 MPa) have been investigated. The study showed that it is possible to obtain two-thirds of room temperature yield stress at $600^{\circ} \mathrm{C}$ with $0 \cdot 20-0 \cdot 25 \% \mathrm{Mo}$ and $0 \cdot 30-0 \cdot 55 \% \mathrm{Cr}$ in low carbon hot rolled structural steel. Microalloying the $\mathrm{Cr}-\mathrm{Mo}$ steel by niobium or vanadium singly or in combination resulted in higher guaranteed elevated temperature yield stress (250-280 MPa). The final rolling temperature should be maintained above austenite recrystallization stop temperature $\left(\sim 900^{\circ} \mathrm{C}\right)$ to minimize dislocation hardening. In a quenched and self-tempered 600 MPa class TMT reinforcement bar steel (YS: 624 MPa), low chromium $(0.55 \%)$ addition produced the requisite yield stress at $600^{\circ} \mathrm{C}$. The low-alloy fire resistant steel will have superior thermal conductivity up to $600^{\circ} \mathrm{C}(>30 \mathrm{~W} / \mathrm{m} \cdot \mathrm{k})$ compared to more concentrated alloys.
\end{abstract}

Keywords. Fire resistant steel; thermomechanical processing; microstructure; strength; thermal conductivity.

\section{Introduction}

Steel structures using mild steel in fire sensitive areas are protected from fire by providing fire resistant coating or insulation. This adds to the constructional cost. The problem with unprotected carbon-manganese mild steel is its poor strength at temperatures above $\sim 350^{\circ} \mathrm{C}$, which can make a structure unsafe after a major fire. In case of short duration fire, it is rather difficult to assess the damage to structures caused by fire and may call for demolition/renovation of the structures. Most of the research efforts relating to construction in fire sensitive areas were directed towards development of steels that can retain adequate strength after prolonged exposure in fire. The building codes of some specifications require the steel to have a minimum of one-half (ASTM 1996) to two-thirds (Fushioni et al 1995; BIS 2002) of room temperature yield strength at $500-600^{\circ} \mathrm{C}$ compared to the mild steel which retains about one-third of room temperature yield strength at $600^{\circ} \mathrm{C}$. In order to achieve this strength level, the steel chemistry and manufacturing process are closely controlled. Previous studies on microstructure and mechanical properties of fire resistant steels carried out by Chijiwa et al (1993) and Assefpour-Dezfully et al (1990) focussed on processing, structure and properties of fire resistant steels with different combinations of alloying elements. In the present investigation, the effect of lower alloying addition, particularly molybdenum, on the elevated temperature properties will be discussed which is important due to increasing alloy cost. Over and above, there is hardly

(panigrahi@sail-rdcis.com) any information on alloying required to obtain two-thirds of room temperature yield stress at $600^{\circ} \mathrm{C}$ for thermomechanically treated (TMT) rebar particularly, the high strength variety with yield strength above $600 \mathrm{MPa}$. The present work was carried out to ascertain minimum requirement of molybdenum/chromium in steels with and without microalloying elements in order to achieve the guaranteed strength at $600^{\circ} \mathrm{C}$ in plate, structurals and TMT rebar and their effects on structure and properties.

\section{Experimental}

Six experimental laboratory heats (steels A-F) and one industrial heat (steel $\mathrm{G}$ ) were melted in $0 \cdot 1 \mathrm{~T}$ air induction (IF) and $6 \mathrm{~T}$ electric arc furnace (EAF), respectively for processing to plate and beam. The ingots from IF heats were soaked at $1250^{\circ} \mathrm{C}$ for $2 \mathrm{~h}$ and thermomechanically processed (TMP) in an experimental rolling mill to $12-14 \mathrm{~mm}$ thick plates in nine passes. The ingot from EAF heat was soaked at $1320^{\circ} \mathrm{C}$ for $4 \mathrm{~h}$ and rolled to blooms of size $230 \times$ $160 \mathrm{~mm}$. These blooms were soaked at $1250^{\circ} \mathrm{C}$ and subsequently thermomechanically processed to $200 \times 100 \mathrm{~mm}$ beam section. The finishing rolling temperatures (FRT) for plates and beam were measured with an infrared pyrometer up to an accuracy of $\pm 5^{\circ} \mathrm{C}$ and were between 800 and $925^{\circ} \mathrm{C}$. The finishing pass reduction was $20-30 \%$ for plates and about $10 \%$ for beam. The plates and beam were allowed to cool in natural air after rolling. Another heat (steel $\mathrm{H}$ ) was made in $250 \mathrm{~T}$ twin hearth furnace and cast as $9 \mathrm{~T}$ ingots for processing to TMT rebar. The ingots were rolled to billets of size $100 \times 100 \mathrm{~mm}$ after soaking at $1300^{\circ} \mathrm{C}$ for $4 \mathrm{~h}$. These billets were subsequently reheated at $1250^{\circ} \mathrm{C}$ 
and processed to TMT rebar of $32 \mathrm{~mm}$ diameter through a Thermex cooling system.

Round tensile specimens (dia. $6 \cdot 25 \mathrm{~mm}$ ) were machined from the quarter width position of the plates (width of plate: $135 \mathrm{~mm}$ ) in the longitudinal direction as per ASTM A 370 standard and tested at room temperature $\left(30^{\circ} \mathrm{C}\right)$ and at elevated temperatures up to $600^{\circ} \mathrm{C}$ at cross head speed of $2 \mathrm{~mm} / \mathrm{min}$ in a servohydraulic test machine as per ASTM E 8 and E 21 standards, respectively. Tensile testing of plates was also carried out selectively at room temperature after exposure at $600^{\circ} \mathrm{C}$ for $3 \mathrm{~h}$ under applied stress of $140 \mathrm{MPa}$. The specimens after exposure were allowed to cool to room temperature inside the furnace. In the elevated temperature test of plates the specimens were heated from room temperature to the test temperature and soaked at the desired temperature for $15 \mathrm{~min}$ before tensile stress was applied. The accuracy of the test temperature was controlled within $\pm 1^{\circ} \mathrm{C}$. Charpy V-notch impact test specimens of size $10 \times 10 \times 55 \mathrm{~mm}$ from steels $\mathrm{A}-\mathrm{F}$ were machined across the plate width in the longitudinal direction and tested at RT to $-30^{\circ} \mathrm{C}$ as per ASTM E 23 standard. The optical microstructure was examined in the longitudinal through thickness direction after polishing and etching by $2 \%$ nital. The average grain size was measured by linear intercept method. Transmission electron microscopic (TEM) investigation was carried out using thin foils prepared from mechanically thinned strip of thickness below $0.1 \mathrm{~mm}$. The electropolishing was done in a twin jet polisher using a solution of $5 \%$ perchloric acid and $95 \%$ glacial acetic acid at $20^{\circ} \mathrm{C}$ and $60 \mathrm{~V}$ operating voltage. The foils were observed at $200 \mathrm{keV}$.

Flat tensile specimens (gauge length: 5.65 Varea) were prepared in the longitudinal direction from the web of the beam as per IS 2062 standard (BIS 1998). The ambient and elevated temperature tensile testing was conducted as described for plates. Tensile testing was also done after an aging treatment at $600^{\circ} \mathrm{C}$ for $3 \mathrm{~h}$ under applied tensile stress of $140 \mathrm{MPa}$. Charpy V-notch specimens (size $7.5 \times 10 \times 55 \mathrm{~mm}$ ) were prepared from the flange region as described in IS 2062 standard and tested as described for plate in the longitudinal direction. The optical microstructure was examined in the longitudinal through thickness direction after polishing and etching by $2 \%$ nital. The average grain size was measured by linear intercept method. TEM specimens were prepared from the flange region as described for plate and observed at $200 \mathrm{keV}$. Full scale fire resistance test was carried out on beam section (size $200 \times 100 \times 3900 \mathrm{~mm}$ ) as per ASTM E 119 standard (ASTM 1996) at Fire Research Laboratory, CSIR, Roorkee, India. The bare beam was mounted on the specimen frame holder of a gas fired furnace. The furnace was rectangular in shape. The casing was made up of steel reinforced sections. The refractory lining of the furnace consisted of front layer of kyanite insulation bricks backed by hot face insulation. The burner casing was made up of fire bricks. The complete furnace assembly consisted of four walls and the open roof top for mounting the beam specimen. The flue gas for heating passed through a duct surrounding the sides of the walls and then was disposed off through a chimney. There were ten long flame burners. The capacity of each burner was $35-40 \mathrm{l} / \mathrm{h}$. The furnace was run on positive pressure. The heating of the specimen was done as specified in ASTM E119 standard. The thermocouples were fixed at four different sections of the beam to measure the rise of temperature at different intervals. While plotting the temperature vs time curves, average temperature measured by concerned thermocouples in a section was used.

Tensile testing of rebar was done using unmachined rebar (gauge length: 5 dia.) at ambient temperature in a $60 \mathrm{~T}$ servo hydraulic tensile testing machine at a cross head speed of $10 \mathrm{~mm} / \mathrm{min}$. For the elevated temperature test at $600^{\circ} \mathrm{C}$, round specimens were used from the core region of rebar and tested as described for plate material. Charpy V-notch impact specimens were also prepared from the location described previously (Panigrahi and Jain 2002) and tested similar to plate. The optical microstructure was examined in the transverse section after polishing and etching by $3 \%$ nital. TEM specimens were prepared from the rim and core regions of the rebar as described for plate and observed at $200 \mathrm{keV}$.

\section{Results and discussion}

\subsection{Chemical composition}

In a structural steel, the composition will be determined by the requirement of strength, toughness and weldability. The chemical composition of steels is given in table 1 . The carbon was $0 \cdot 11-0.13 \%$ in plate, $0.17 \%$ in structural beam and $0.25 \%$ in TMT rebar. The conventional way to improve moderately the strength at elevated temperature (up to $\sim 350^{\circ} \mathrm{C}$ ) is by increasing the carbon content (Houdremont 1953). Lower carbon in hot-rolled steel improves notch toughness and weldability. In TMT rebar carbon increases the hardenability. Manganese increases the strength by solid solution hardening (Baird and Jamieson 1972) in hot rolled steel. Manganese tends to lower the eutectoid carbon content in steel and promotes segregation particularly in hot rolled structural steel with carbon $>0 \cdot 10 \%$. This can adversely affect the mechanical properties. Manganese was restricted to $1 \%$ in fire resistant hot rolled plate and structural with carbon $0 \cdot 10-0 \cdot 20 \%$ and $1.5 \%$ in TMT rebar where manganese is a potential hardenability enhancing element. Silicon content in steels $A-G$ varied from $0 \cdot 29-0 \cdot 35 \%$. Silicon is a solid solution strengthener and a deoxidizer. Silicon retards softening at high temperatures (Irvine 1962) and also increases the hardenability. However, in steel $\mathrm{H}$, its content was low due to technoeconomic reasons. The aluminium $(0.01-0.02 \%)$ is required to tie-up free nitrogen to improve toughness. In the steels A, D, E and F, the content of aluminium was 
Table 1. Chemical composition of steels (wt.\%).

\begin{tabular}{|c|c|c|c|c|c|c|c|c|}
\hline Steel & A & B & $\mathrm{C}$ & D & E & $\mathrm{F}$ & $\mathrm{G}$ & $\mathrm{H}$ \\
\hline $\mathrm{C}$ & $0 \cdot 11$ & $0 \cdot 12$ & $0 \cdot 12$ & $0 \cdot 13$ & $0 \cdot 13$ & $0 \cdot 12$ & $0 \cdot 17$ & $0 \cdot 25$ \\
\hline $\mathrm{Mn}$ & 1.02 & 1.02 & 1.08 & 0.99 & 1.00 & 0.96 & 0.74 & 1.42 \\
\hline $\mathrm{Si}$ & $0 \cdot 35$ & $0 \cdot 35$ & $0 \cdot 29$ & $0 \cdot 31$ & $0 \cdot 31$ & $0 \cdot 30$ & $0 \cdot 31$ & $0 \cdot 056$ \\
\hline S & 0.022 & 0.032 & 0.029 & 0.025 & 0.026 & $0 \cdot 025$ & 0.034 & $0 \cdot 024$ \\
\hline $\mathrm{P}$ & $0 \cdot 019$ & 0.025 & 0.027 & $0 \cdot 021$ & $0 \cdot 022$ & 0.021 & 0.027 & $0 \cdot 024$ \\
\hline $\mathrm{Cr}$ & $0 \cdot 31$ & $0 \cdot 29$ & $0 \cdot 40$ & $0 \cdot 38$ & $0 \cdot 39$ & $0 \cdot 38$ & 0.54 & $0 \cdot 55$ \\
\hline Mo & $0 \cdot 26$ & $0 \cdot 20$ & $0 \cdot 14$ & $0 \cdot 26$ & $0 \cdot 26$ & $0 \cdot 26$ & $0 \cdot 22$ & - \\
\hline $\mathrm{Nb}$ & - & - & - & 0.02 & - & 0.02 & - & - \\
\hline V & - & - & - & - & 0.07 & $0 \cdot 12$ & - & - \\
\hline $\mathrm{Al}$ & 0.0033 & 0.099 & 0.097 & 0.0034 & 0.0039 & 0.0039 & 0.052 & $0 \cdot 004$ \\
\hline $\mathrm{N}$ & 0.0042 & $0 \cdot 0063$ & 0.0067 & $0 \cdot 0047$ & 0.0047 & $0 \cdot 0070$ & $0 \cdot 0124$ & 0.0075 \\
\hline
\end{tabular}

lower than the prescribed range. The rebar steel was semi-killed. Chromium in small percent forms $(\mathrm{FeCr})_{3} \mathrm{C}$ (Houdremont 1953) in the cementite of pearlite. It is a ferrite stabilizer and increases the hardenability. However, its potential as a solid solution strengthening element is small due to its high affinity to carbon. The amount of chromium was $0.29-0.40 \%$ in plate and $0.55 \%$ in structural beam and TMT rebar. Molybdenum increases elevated temperature yield strength (Argent et al 1970; Honeycombe 1981) even when present in small percent $(\sim 0.25 \%)$ in solid solution in low carbon steel. It also forms carbide $(\mathrm{Fe}, \mathrm{Mo})_{3} \mathrm{C}$ in the cementite of pearlite resisting softening on prolonged exposure in a fire (Houdremont 1953). Molybdenum tends to hinder self-diffusion of iron (Houdremont 1953), thus increasing the recrystallization temperature of steel. Microalloying elements, vanadium and niobium, increase the elevated temperature strength (Pickering 1978; Sage 1983). They also increase the recrystallization temperature of steel (Borato et al 1988). Their carbides also offer resistance to softening when the steel is exposed to fire. The chemistry of the present investigation differs from the previous studies (Assefpour-Dezfully et al 1990; Chijiwa et al 1993; Fushioni et al 1995) in the following ways: (a) the content of molybdenum and chromium is low, (b) low niobium and vanadium are used in microalloyed steels and (c) chromium without molybdenum has been used in TMT rebar.

\subsection{Thermomechanical processing (TMP)}

Processing plays an important role since it determines the final microstructure and mechanical properties of hot rolled steel (Panigrahi 2004). The TMP schedule for plate and beam is shown in figure 1. TMP of plate and beam involves controlled deformation of austenite at higher temperatures above the recrystallization stop temperature $\left(t_{\mathrm{nr}}\right)$ (Borato et al 1988) during which static and dynamic restoration processes occur (Tanaka 1981). Table 2 shows data on total reduction, approximate recrystallization stop temperature, finishing temperature and grain size of steels.
As the finish rolling temperatures (FRT) of all steels except steel $\mathrm{F}$ and a few structurals of steel $\mathrm{G}$ were above $t_{\mathrm{nr}}$, an equiaxed ferrite microstructure could be obtained with low dislocation density. Steel $\mathrm{F}$ was finish rolled at $800^{\circ} \mathrm{C}$, quite below $t_{\mathrm{nr}}\left(884 \cdot 1^{\circ} \mathrm{C}\right)$ but above $\mathrm{Ar}_{3}$ temperature $\left(771^{\circ} \mathrm{C}\right)$ (Ouchi et al 1982). Deformation in this region strain hardened the austenite, increasing its dislocation density. Deformation bands are also formed (Tanaka 1981). Since ferrite nucleates both on austenite grain boundaries and deformation bands, the grains are finest $(7.7 \mu \mathrm{m})$. However, the cellular structure retained by rolling below $t_{\mathrm{nr}}$, lowered the yield strength at elevated temperatures.

In the processing of TMT rebar (figure 1), initially at higher temperatures $\left(1200-1100^{\circ} \mathrm{C}\right)$ the material recrystallizes statically. At the intermediate and finishing stages of processing $\left(1000-1050^{\circ} \mathrm{C}\right)$, static, dynamic as well as metadynamic recrystallization of austenite can occur (Poliak and Jonas 2003) depending upon strain at different passes producing an equiaxed austenite structure. On leaving the finishing stand at $1000-1050^{\circ} \mathrm{C}$, the bar enters a Thermex cooling chamber where the surface of the bar is cooled by pressurized water at $\sim 200^{\circ} \mathrm{C} / \mathrm{s}$ forming a thin rim of lath martensite while the core is still austenite. On emergence from the cooling chamber, the martensite rim gets selftempered by the heat of the core and the core finally transforms to bainite.

\subsection{Microstructure}

Typical optical microstructures of some steels in as-rolled condition are shown in figure 2. The $\mathrm{Cr}-\mathrm{Mo}$ (steel A) and $\mathrm{Cr}-\mathrm{Mo}-\mathrm{Nb}$ (steel D) alloyed plates (figures $2 \mathrm{a}$ and $\mathrm{b}$ ) and beam (figure $2 \mathrm{c}$ ) showed a predominantly polygonal ferrite-pearlite microstructure. At higher magnification, steel A (figure 2d) also showed upper bainite (arrow mark). The bainite in steel A resembles pearlitic bainite (Bhadeshia 1992) as the colonies tend to have crystallographic facets rather than nicely rounded colonies of conventional pearlite. The vanadium (steel E) and niobium plus vanadium (steel F) microalloyed steels also showed similar micro- 


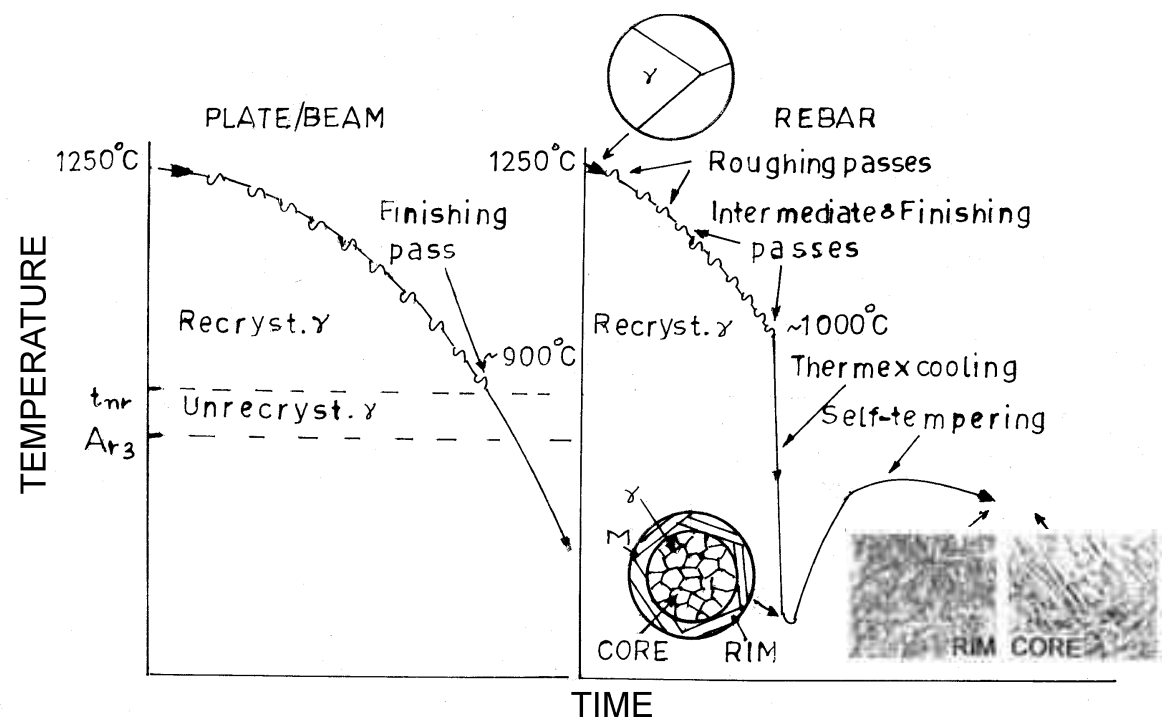

Figure 1. Schematic of TMP schedule for plate, beam and TMT rebar (M, martensite; $\gamma$, austenite).

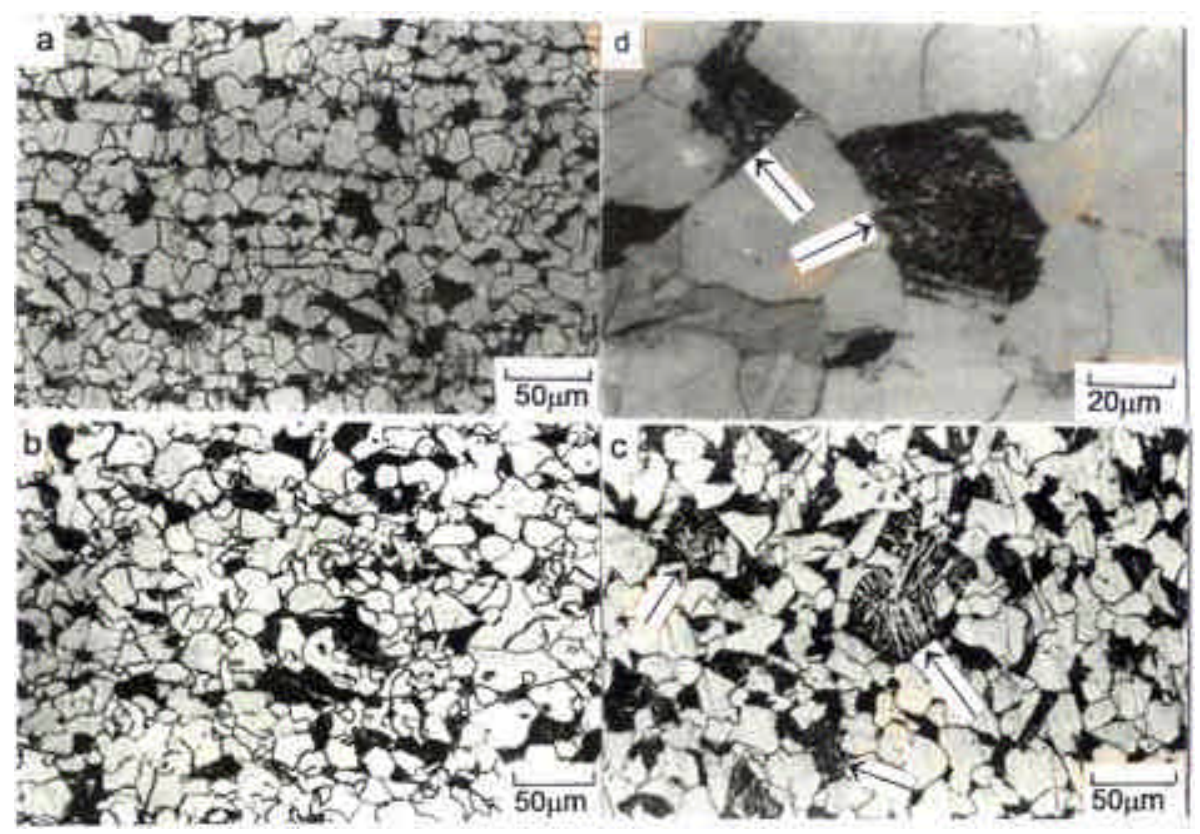

Figure 2. As hot rolled microstructures of a. Cr-Mo plate (steel A), b. Cr-Mo-Nb plate (steel D), c. Cr-Mo beam (steel G) and d. pearlitic bainite of $\mathrm{Cr}-\mathrm{Mo}$ plate (steel A).

Table 2. Process parameters and microstructural data.

\begin{tabular}{lccccccc}
\hline Steels & $\begin{array}{c}\text { Thickness } \\
(\mathrm{mm})\end{array}$ & $\begin{array}{c}\text { Total } \\
\text { reduction }(\%)\end{array}$ & $t_{\text {nr }}\left({ }^{\circ} \mathrm{C}\right)$ & $\begin{array}{c}\text { FRT } \\
\left({ }^{\circ} \mathrm{C}\right)\end{array}$ & Structure & $\begin{array}{c}\text { Grain size } \\
(\mu \mathrm{m})\end{array}$ & Product \\
\hline $\mathrm{A}$ & 14 & 86 & $814 \cdot 0$ & 900 & $\mathrm{~F}+\mathrm{P}+\mathrm{B}$ & $10 \cdot 4$ & Plate \\
$\mathrm{B}$ & 12 & 88 & $853 \cdot 5$ & 900 & $\mathrm{~F}+\mathrm{P}$ & $13 \cdot 5$ & Plate \\
$\mathrm{C}$ & 12 & 88 & $874 \cdot 3$ & 900 & $\mathrm{~F}+\mathrm{P}$ & $12 \cdot 5$ & Plate \\
$\mathrm{D}$ & 12 & 88 & $876 \cdot 9$ & 900 & $\mathrm{~F}+\mathrm{P}+\mathrm{B}$ & $11 \cdot 0$ & Plate \\
$\mathrm{E}$ & 12 & 88 & $828 \cdot 5$ & 875 & $\mathrm{~F}+\mathrm{P}+\mathrm{B}$ & $12 \cdot 5$ & Plate \\
$\mathrm{F}$ & 12 & 88 & $884 \cdot 1$ & 800 & $\mathrm{~F}+\mathrm{P}+\mathrm{B}$ & $7 \cdot 7$ & Plate \\
$\mathrm{G}$ & - & $94 *$ & 874 & $850-925$ & $\mathrm{~F}+\mathrm{P}+\mathrm{B}$ & $10 \cdot 3$ & Beam \\
$\mathrm{H}$ & - & 92 & $984 \cdot 4$ & 1000 & $\mathrm{M}+\mathrm{B}$ & - & Rebar \\
\hline
\end{tabular}

F, Ferrite; P, pearlite; B, bainite; M, tempered martensite; *flange region; $t_{\mathrm{nr}}=887+$ $464 \% \mathrm{C}+(6645 \% \mathrm{Nb}-664 \sqrt{\%} \mathrm{Nb})+(732 \% \mathrm{~V}-230 \sqrt{ } \% \mathrm{~V})+890 \% \mathrm{Ti}+363 \% \mathrm{Al}-357 \% \mathrm{Si}$ 

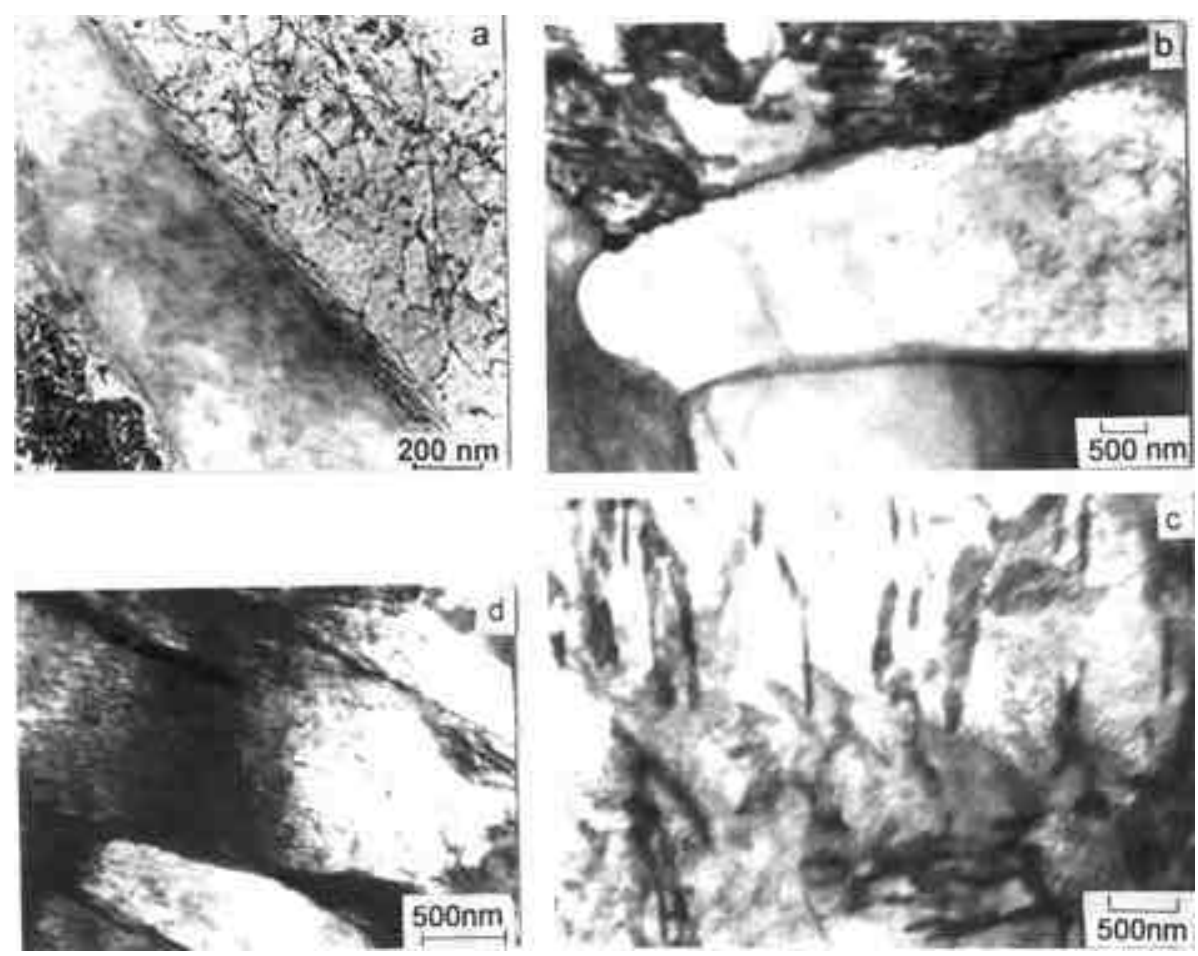

Figure 3. Bright field TEM of a. Cr-Mo-Nb-V plate (steel F), b. and c. Cr-Mo beam (steel G) and d. TMT rebar.

structures. The bainite 'colonies' in steel G were coarser than steels A, D, E and F and were more numerous possibly due to presence of somewhat higher carbon and chromium in this steel, lower reduction per pass and coarser austenite grains prior to transformation. The bainite was not observed in steels $\mathrm{B}$ and $\mathrm{C}$. The finishing rolling in the austenite region above recrystallization stop temperature helped to form polygonal ferrite grain structure in $\mathrm{Cr}-\mathrm{Mo}, \mathrm{Cr}-\mathrm{Mo}-\mathrm{Nb}$ and $\mathrm{Cr}-\mathrm{Mo}-\mathrm{V}$ plate steels. In this case ferrite nucleates on austenite grain boundaries (Tanaka 1981). Cr-Mo-Nb-V plate (steel F) was finish rolled in the unrecrystallized austenite region producing grain size finer than other steels (table 2) due to nucleation of ferrite on austenite grain boundaries, transgranular twins and deformation bands (DeArdo 1995; Panigrahi 2001) after transformation. The partial cellular structure of steel $\mathrm{F}$ with dislocations retained is shown in figure $3 \mathrm{a}$. The beam steel also showed upper bainite (figure $3 b$ ) with cementite particles distributed between ferrite platelets (figure $3 \mathrm{c}$ ). An exposure treatment up to $3 \mathrm{~h}$ at $600^{\circ} \mathrm{C}$ did not show changes in the appearance of microstructure. Unlike martensite in which dissolved carbon in solid solution is high, bainite has little carbon in solid solution and is much less sensitive to tempering at low temperatures $\left(\sim 600^{\circ} \mathrm{C}\right)$. However, cementite particles can coarsen and a general recovery of dislocation substructure occurs (Bhadeshia 1992). The TMT rebar steel showed a tempered martensite rim. The core structure was bainitic (figure $3 \mathrm{~d}$ ) due to high hardenability of this steel.

\subsection{Elevated temperature yield stress}

The dependence of yield stress and UTS with temperature for steels $A-G$ is shown in figure 4. Steel $F$ showed a faster drop of yield stress after $500^{\circ} \mathrm{C}$. However, except steel C $(0 \cdot 14 \% \mathrm{Mo})$ whose yield stress was marginally below the desired level at $600^{\circ} \mathrm{C}$, all other steels retained two-thirds of their room temperature yield strength at $600^{\circ} \mathrm{C}$ (table 3 ). The elevated temperature yield stress depends mainly on the stability of microstructure at higher temperatures. Chromium and molybdenum have a stabilizing effect on cementite of pearlite (Houdremont 1953). A higher amount of chromium in steel $\mathrm{C}$ prevented excessive drop of yield stress at $600^{\circ} \mathrm{C}$ despite low molybdenum $(0 \cdot 14 \%)$ in it. Steels D and E that are microalloyed with $\mathrm{Nb}$ and $\mathrm{V}$, respectively have highest level of yield stress at $600{ }^{\circ} \mathrm{C}$ viz. $82 \%$ and $85 \%$, respectively. $\mathrm{Nb}$ and $\mathrm{V}$ have added advantages due to their precipitation hardening potential and the loss of strength at higher temperature is minimal. The rapid drop of yield stress of steel $\mathrm{F}$ above $500^{\circ} \mathrm{C}$ was due to lowering of dislocation density on soaking above $500^{\circ} \mathrm{C}$. The UTS of all steels fell sharply above $400^{\circ} \mathrm{C}$ (figure 4). The elongation of all steels at $600^{\circ} \mathrm{C}$ was higher than elongation at the ambient temperature. Exposure at $600^{\circ} \mathrm{C}$ for $3 \mathrm{~h}$ increased the yield stress by about $50 \mathrm{MPa}$ without significant change in elongation in steels A, D, E, F and G. The core of rebar steel $\mathrm{H}$ with bainitic structure also showed two-thirds of room temperature yield stress at $600^{\circ} \mathrm{C}$ (table 3). Due to presence of 

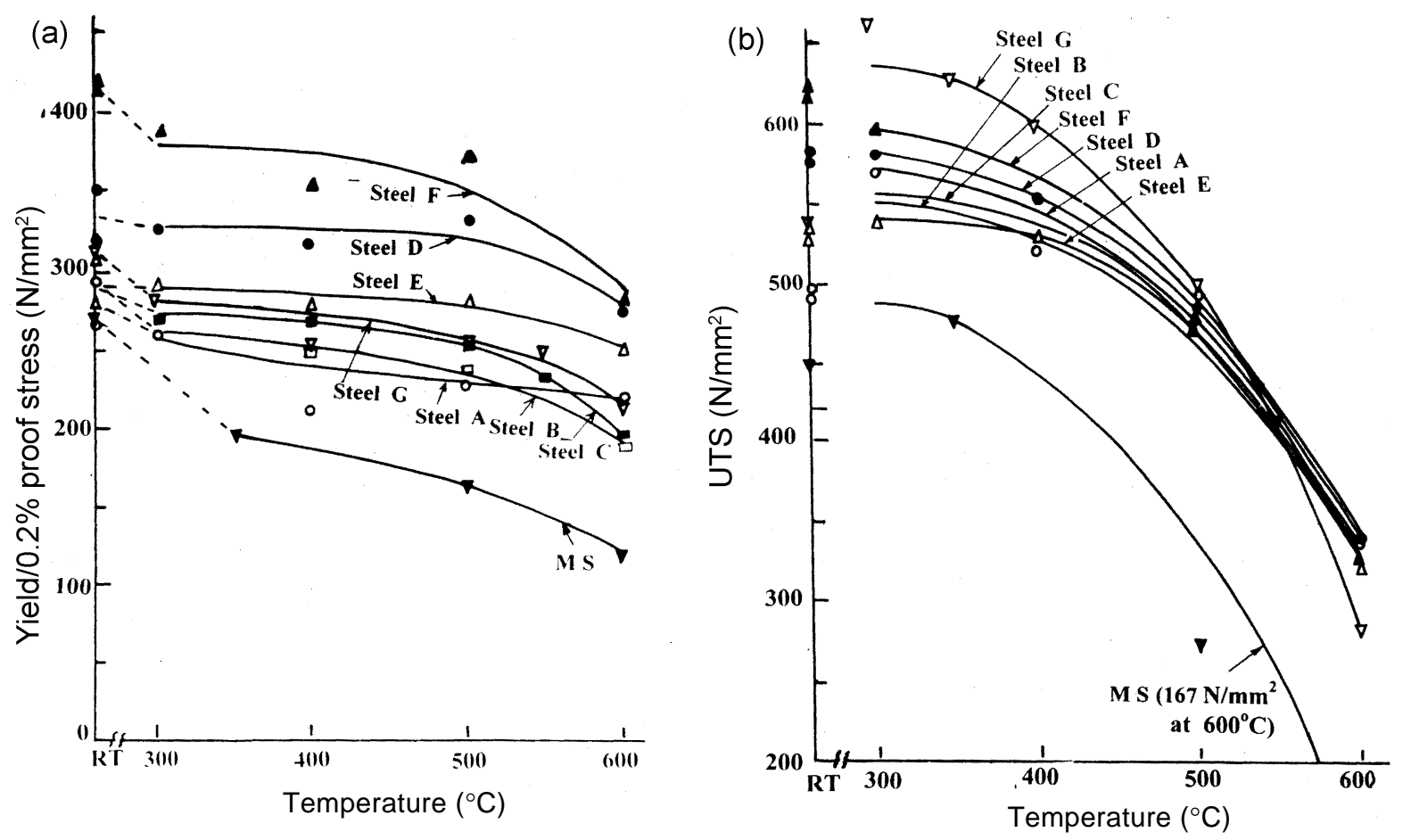

Figure 4. Dependence of (a) yield stress and (b) UTS on temperatures of fire resistant steels and mild steel (MS).

Table 3. Tensile properties of the investigated steels.

\begin{tabular}{lcccccccc}
\hline Steel & A & B & C & D & E & F & G & H \\
\hline Ambient temperature (RT) & & & & & & & & \\
$\quad$ YS (MPa) & 287 & 293 & 298 & 338 & 293 & 415 & 320 & 624 \\
UTS (MPa) & 505 & 486 & 539 & 582 & 530 & 622 & 541 & 819 \\
El. (\%) & $38 \cdot 0$ & $36 \cdot 2$ & $32 \cdot 0$ & $30 \cdot 0$ & $37 \cdot 8$ & $26 \cdot 8$ & $27 \cdot 3$ & $12 \cdot 5$ \\
Elevated temperature $\left(600^{\circ} \mathrm{C}\right)$ & & & & & & & & \\
YS (MPa) & 219 & 191 & 188 & 279 & 250 & 280 & 214 & 419 \\
UTS (MPa) & 326 & 259 & 247 & 332 & 327 & 338 & 292 & 426 \\
El. (\%) & $42 \cdot 2$ & $41 \cdot 7$ & $49 \cdot 0$ & $40 \cdot 4$ & $36 \cdot 2$ & $46 \cdot 0$ & $33 \cdot 0$ & $30 \cdot 5$ \\
\% of room temperature YS & $76 \cdot 3$ & $65 \cdot 1$ & $63 \cdot 0$ & $82 \cdot 5$ & $85 \cdot 3$ & $67 \cdot 4$ & $66 \cdot 8$ & $67 \cdot 1$ \\
After thermal exposure at $600^{\circ} \mathrm{C}$ under applied stress & & & & & \\
$\quad$ YS (MPa) & 360 & - & - & 408 & 348 & 469 & 369 & - \\
UTS (MPa) & 432 & - & - & 523 & 475 & 584 & 492 & - \\
El. (\%) & $22 \cdot 5$ & - & - & $30 \cdot 8$ & $34 \cdot 0$ & $22 \cdot 8$ & $27 \cdot 0$ & - \\
\hline
\end{tabular}

tempered martensite rim, the overall strength of TMT rebar at $600^{\circ} \mathrm{C}$ should be higher than two-thirds of its room temperature yield strength. In a composite microstructure comprising tempered martensite rim and bainitic core, the overall yield stress is given by area fraction of rim multiplied by yield stress of rim plus area fraction of core multiplied by yield stress of core. The area fraction of bainite core was 0.766 and that of tempered martensite rim was 0.234. Previous investigation (Panigrahi 2002) showed that low-alloyed tempered martensite structure had more than two-thirds of room temperature yield stress at $600^{\circ} \mathrm{C}$.

\subsection{Impact toughness}

The ambient temperature impact toughness, 50\% energy ductile brittle transition temperature (DBTT) (Dahl 1992) and fracture characteristics are given in table 4. The upper shelf energy of as-rolled plate and beam varied from 65$118 \mathrm{~J}$ (figure 5). The steels A, D, E and F showed DBTT at $-4^{\circ} \mathrm{C}$ to $-12^{\circ} \mathrm{C}$. The DBTT of steel B was below $-30^{\circ} \mathrm{C}$ and that of steel $\mathrm{C}$ was $-28^{\circ} \mathrm{C}$. Presence of upper bainite in all steels except steels $\mathrm{B}$ and $\mathrm{C}$, low aluminium content (steels A, D, E and F) and cellular structure (steel F) were responsible for increase in DBTT. Notwithstanding 
higher carbon content, steel $\mathrm{H}$ showed a DBTT of $-14^{\circ} \mathrm{C}$ due to presence of tempered martensite and some acicular ferrite in it. Steel $\mathrm{G}$ showed a DBTT of $-5^{\circ} \mathrm{C}$ in as rolled condition and $-34^{\circ} \mathrm{C}$ in aged condition. The DBTT of steel $\mathrm{G}$ in as rolled condition was higher than steel A possibly due to presence of relatively coarser 'colonies' of pearlitic bainite in its microstructure and a higher carbon content (0.17\%) (Pickering 1978) compared to steel A $(0.11 \%$

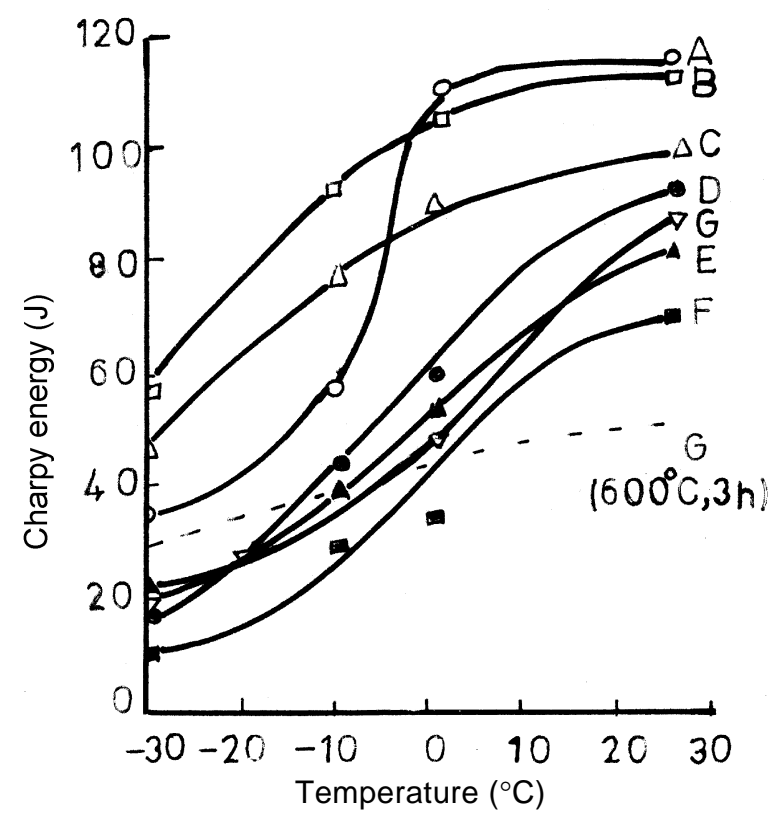

Figure 5. Charpy energy vs temperature curves of plates and beam.

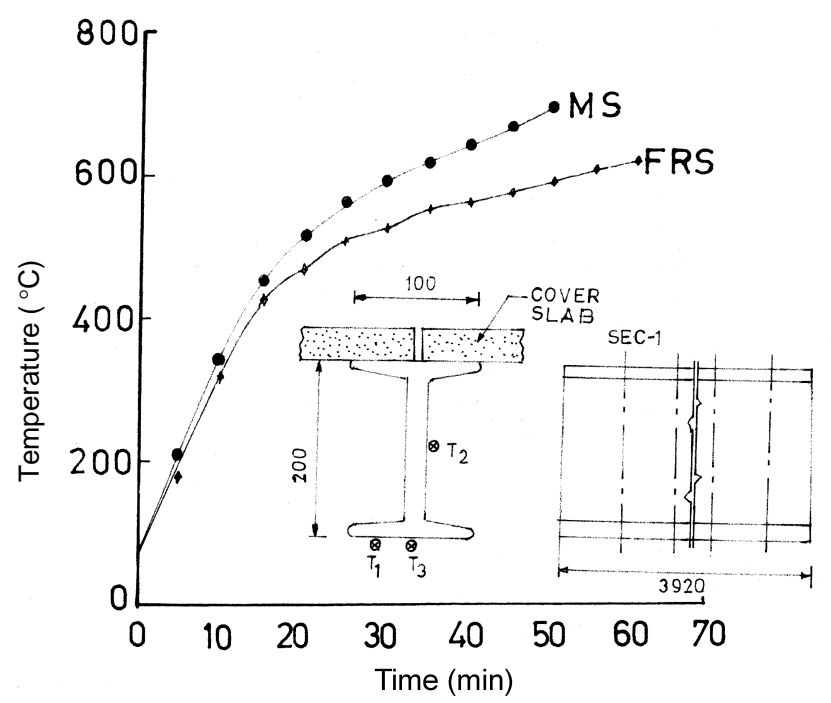

Figure 6. Typical time-temperature curves for $\mathrm{Cr}-\mathrm{Mo}$ beam (steel $G$ ) and mild steel $\left(T_{1}, T_{2}\right.$ and $T_{3}$ are locations of thermocouples at section 1 ). carbon). On exposure at $600^{\circ} \mathrm{C}$, the improved toughness (DBTT: $-34^{\circ} \mathrm{C}$ ) of steel $\mathrm{G}$ could be due to lowering of dislocation density of bainite and diffusion of embrittling atoms present on the grain boundaries to the dislocations. Improvement of impact transition temperature by diffusion of phosphorus from prior austenite grain boundaries to lattice defects was reported earlier for spring steel (Wettlaufer and Kasper 2000). However, upper shelf energy of aged steel was lower than the as-rolled beam possibly due to microstructural heterogeneity leading to formation of localized carbide rich areas that aided lowering of the absorbed energy.

\subsection{Fire resistance}

The average temperature rise of fire resistant steel (FRS) beam and mild steel (MS) beam $(0.17 \mathrm{C}, 0.69 \mathrm{Mn}, 0.04 \mathrm{Si}$, $0.048 \mathrm{~S}, 0.028 \mathrm{P}, 0.007 \mathrm{Al})$ is shown in figure 6 for section

Table 4. Charpy toughness data.

\begin{tabular}{lccc}
\hline Steel & $\begin{array}{c}\text { Toughness at RT } \\
(\text { Joule })\end{array}$ & $\begin{array}{c}\text { DBTT } \\
\left({ }^{\circ} \mathrm{C}\right)\end{array}$ & $\begin{array}{c}\text { Fracture } \\
\text { surface at RT }\end{array}$ \\
\hline A & 118 & -12 & Dimple \\
B & 116 & $<-30$ & Dimple \\
C & 100 & -28 & Dimple \\
D & 94 & -9 & Dimple \\
E & 82 & -8 & Dimple \\
F (as rolled) & 73 & -4 & Dimple \\
G G (after thermal exposure & 57 & -5 & Dimple \\
at $\left.600^{\circ} \mathrm{C}\right)$ & & -34 & Dimple \\
H & 88 & -14 & Quasi cleavage \\
\hline
\end{tabular}

Note: All values of toughness are for full size specimens.

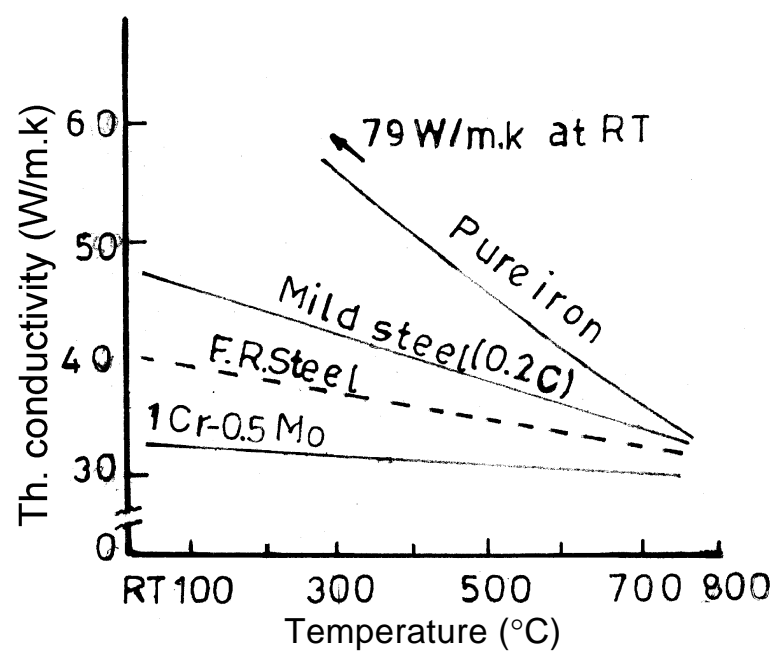

Figure 7. Dependence of thermal conductivity of dilute steel alloys on temperatures. 
1 (inset). The rise of temperatures up to $600^{\circ} \mathrm{C}$ for other sections was similar to section 1 . It was observed that the temperature of the fire resistant steel was at a lower level compared to mild steel. The data points for these curves remain below the ASTM E 119 standard time-temperature curve in a fire test (ASTM 1996). The time to reach the critical temperature $\left(538^{\circ} \mathrm{C}\right)$ was $32 \mathrm{~min}$ and $21 \mathrm{~min}$ for fire resistant steel and mild steel, respectively. The rate of heating is dependent on the thermal conductivity which is a material property governing the flow of heat through a material at steady state. Figure 7 shows the dependence of thermal conductivity with temperature for pure iron and some constructional steels (Riemann 1953; McGannon 1966). The thermal conductivity of pure iron and dilute alloys decreases with rising temperature. The likely behaviour of $0.5 \mathrm{Cr}-0.22 \mathrm{Mo}$ fire resistant steel which is a dilute alloy is also shown in this figure. Its conductivity should be higher than $30 \mathrm{~W} / \mathrm{m} \cdot \mathrm{k}$ at $600^{\circ} \mathrm{C}$. The dominant carrier of the thermal conduction in pure metals and dilute alloys is electrons (Ho et al 1975; Isachenko et al 1980; Touloukian and Ho 1981; Landolt 1991). When small amount of alloying elements (impurities) are introduced in iron, it causes discontinuities in the crystal lattice structure and promotes scattering of free electrons decreasing the room temperature thermal conductivity (Riemann 1953; McGannon 1966). With rising temperature, the scattering of free electrons is intensified (Isachenko et al 1980). This causes a net reduction of thermal conductivity at higher temperature. Even then the thermal conductivity of dilute steel alloy is still high $(>30 \mathrm{~W} / \mathrm{m} \cdot \mathrm{k})$ at $600^{\circ} \mathrm{C}$. Since in a fire, temperature gradients are encountered, a high thermal conductivity material is desired to avoid degradation by local necking.

\section{Conclusions}

Small additions of Mo (0.20-0.25\%) and Cr (0.30-0.55\%) in low carbon steel produced hot rolled fire resistant steel with a minimum of two-thirds of room temperature yield stress at $600^{\circ} \mathrm{C}$. Microalloying by niobium and vanadium improved the ratio of $\mathrm{YS}_{600^{\circ} \mathrm{C}} / \mathrm{YS}_{R T}$. However, final rolling temperature should be maintained in the recrystallized austenite region to ensure a microstructure free from high dislocation density. The steels should be adequately treated by aluminium to tie-up free nitrogen in order to realize lower DBTT. In the quenched and self-tempered TMT rebar steel, addition of $\sim 0.55 \%$ chromium was adequate to ensure the guaranteed strength at $600^{\circ} \mathrm{C}$ due to transformation to tempered martensite rim and bainitic core. Despite decreasing trend of thermal conductivity with the rise of temperature in dilute alloys, the low alloy fire resistant steel will have higher thermal conductivity up to $600^{\circ} \mathrm{C}$ (> $30 \mathrm{~W} / \mathrm{m} \cdot \mathrm{k}$ ) compared to more concentrated alloys and is less expensive.

\section{References}

American Society of Testing Materials 1996 Standard test methods for fire tests of building construction and materials, Philadelphia, E119

Argent B B, Niekenk M N and Redfern G A 1970 J. Iron \& Steel Inst. 208830

Assefpour-Dezfully M, Hugas B A and Brownrigg A 1990 Mater. Sci. \& Technol. 61210

Baird J D and Jamieson A 1972 J. Iron \& Steel Inst. 210847

Bhadeshia H K D H 1992 Bainite in steels (London: Institute of Materials)

Borato F, Barbosa R, Yue S and Jonas J J 1988 Proc. Thermec'88 (ed.) I Tamura (Tokyo: Iron and Steel Inst. Japan) p. 388

Bureau of Indian Standards 1998 Indian Standards IS 2062, New Delhi

Bureau of Indian Standards 2002 Indian Standards IS 15103, New Delhi

Chijiwa R, Tamehiro H, Yoshida Y, Funato K, Uemori R and Horii Y 1993 Nippon Steel Tech. Report 5847

Dahl W 1992 Steel (Dusseldorf: Springer Verlag and Verlag Stahl Eisen) 1

DeArdo A J 1995 Microalloying'95 (Warrendale: Iron and Steel Society) p. 15

Fushioni M, Chikaraishi H and Keira K 1995 Nippon Steel Tech Report 6629

Ho C Y, Powell R W and Liley P E 1975 Thermal conductivity of the elements: A comprehensive review (NewYork: AIP)

Honeycombe R W K 1981 Steel microstructure and properties (London: Edward Arnold; Ohio : ASM)

Houdremont E 1953 Handbook of special steels (Berlin: Springer Verlag) 1

Irvine K J 1962 J. Iron \& Steel Inst. 200820

Isachenko V P, Osipova V A and Sukomel A S 1980 Heat transfer (Moscow: Mir Publisher)

Landolt B 1991 Thermal conductivity of pure metals and alloys (eds) O Madelun and G K White (Berlin: Springer Verlag) 15C

McGannon H E (ed.) 1966 Making, shaping and treating of steels (Pittsburgh : USS)

Ouchi C, Sampei T and Kozasu I 1982 Iron \& Steel Inst., Japan 22214

Panigrahi B K 2001 Bull. Mater. Sci. 24361

Panigrahi B K 2002 Unpublished result

Panigrahi B K 2004 Seminar on Structural steel for construction industry (NIT, Rourkela: The Institution of Engineers)

Panigrahi B K and Jain S K 2002 Bull. Mater. Sci. 25319

Pickering F B 1978 Physical metallurgy and design of steels (London: Applied Science Pub.)

Poliak E I and Jonas J J 2003 Iron \& Steel Inst. Japan Int. 43 692

Riemann W 1953 Stahl und Eisen 73721

Sage A M 1983 Proc. int. conf. steels for line pipe and pipe line fittings (London: Metals Soc.) p. 39

Tanaka T 1981 Int. Metal. Rev. 26185

Touloukian Y S and Ho C Y 1981 Properties of selected ferrous alloying elements (New York: McGraw Hill Book Co.) III.1

Wettlaufer M and Kasper R 2000 Steel Res. 71357 